\title{
LOW COEFFICIENT OF THERMAL EXPANSION (CTE) NICKEL BASE SUPERALLOYS FOR INTERCONNECT APPLICATIONS IN INTERMEDIATE TEMPERATURE SOLID OXIDE FUEL CELLS (SOFC)
}

\author{
David E. Alman and Paul D. Jablonski \\ U.S. Department of Energy, Albany Research Center, 1450 Queen Ave, SW. Albany, OR 97321, USA
}

Keywords: Coefficient of Thermal Expansion (CTE), Chromia Former, Oxidation Resistance, Solid Oxide Fuel Cell (SOFC).

\begin{abstract}
This paper deals with the fabrication, microstructure and oxidation resistance of Ni-base alloys with CTE on the order of $12.5 \times 10^{-6} /{ }^{\circ} \mathrm{C}$. Alloys based on the composition $\mathrm{Ni}-(18-22 \mathrm{wt} \%)$ Mo-12Cr-1Ti were readily rolled into $1 \mathrm{~mm}$ strip. Modifications to this base composition, such as increasing $\mathrm{Cr}$ or $\mathrm{Ti}$ content adversely affected the ability to form the alloy. The oxidation resistance at $750^{\circ} \mathrm{C}$ of several of these alloys was superior to a Febase alloy containing significantly more $(22 \mathrm{wt} \%) \mathrm{Cr}$.
\end{abstract}

\section{Introduction}

Solid oxide fuel cells (SOFCs) are energy conversion devices that generate electricity and heat by electrochemically combining a gaseous fuel and an oxidizing gas via an ion-conducting ceramic electrolyte. SOFCs have two very practical advantages over the other fuel cell types. First, internal reforming of hydrocarbons is possible within the cell allowing for fuel flexibility. Second, they can operate using synthesis gas $\left(33 \mathrm{CO}+1 \mathrm{CO}_{2}+66 \mathrm{H}_{2}\right)$ generated from coal gasification, as the anode is not sensitive to $\mathrm{CO}$. A disadvantage of SOFCs is that they must operate at elevated temperatures where ionic ceramics are conductive. A single cell typically produces 0.5 to $0.9 \mathrm{~V}$. To generate a reasonable voltage, these cells are stacked together and electrically connected in series to build up voltage and power delivery capability. Although several stack designs are being considered, the most common configuration is the planar or flat SOFC shown in Figure 1.

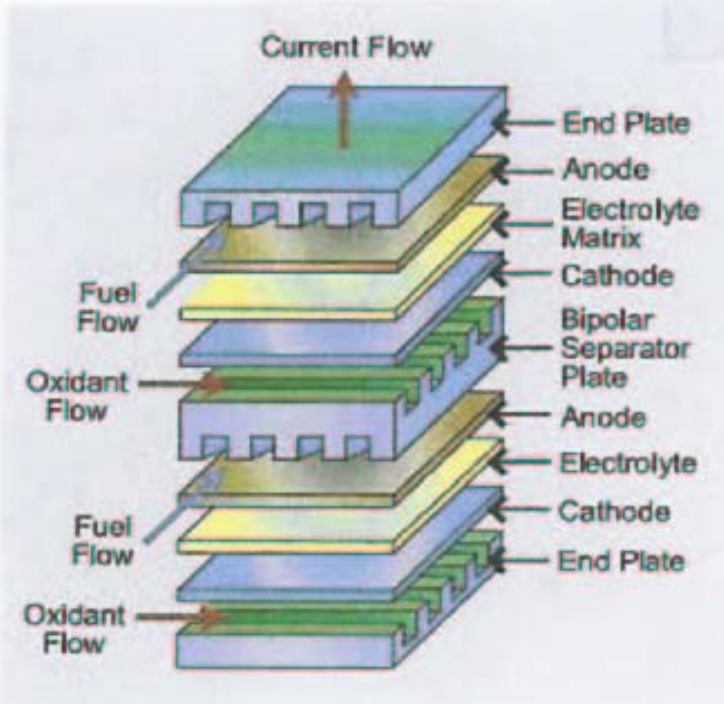

Figure 1. Schematic of a planar Solid Oxide Fuel Cell (SOFC) stack.
The interconnect, also called a bipolar separator plate in Figure 1, is a critical component [1,2], as it provides electrical connection between individual cells; and it serves as a gas separation barrier to prevent mixing of the fuel and air. Therefore, the interconnect must be chemically and physically compatible with the other SOFC components, be stable in the both oxidizing and reducing environments, and be electrically conductive. The oxide scale that forms on metallic alloys will affect the conductivity. Thus, $\mathrm{Cr}_{2} \mathrm{O}_{3}$ forming alloys are preferred for interconnects; since, $\mathrm{Cr}_{2} \mathrm{O}_{3}$ is an intrinsic semiconductor under SOFC operating conditions, where as, $\mathrm{Al}_{2} \mathrm{O}_{3}$ and $\mathrm{SiO}_{2}$ are both insulators [3]. For physical compatibility, the CTE of the interconnect must match that of the ceramic components (CTEs on the order of $12 \times 10^{-6} \mathrm{C}^{-1}$ ).

Replacing the currently used ceramic $\mathrm{LaCrO}_{3}$ interconnects with metallic interconnects can reduce materials costs by $\sim 85 \%[1,2]$. Ferritic stainless steels have CTE values in this range. Hence, there has been considerable effort on developing chromia-forming ferritic alloys for interconnects, culminating with Crofer 22APU (ThyssenKrupp VDM), Hitachi ZMG232 (Hitachi Metals) and EBrite (Allegheny Ludlum). However, these alloys may not have adequate performance characteristics (oxidation and creep resistance) over the projected 40,000-hour life span for SOFC application. A preliminary study conducted at Pacific Northwest National Laboratory (PNNL) [4], demonstrated the superior oxidation and corrosion resistance of a nickel base superalloy (Haynes 230) compared to Crofer 22APU. However, most superalloys, including Haynes 230, have CTEs on the order of $15 \times 10^{-6}{ }^{\circ} \mathrm{C}^{-1}$, too high for the interconnect application. Thus, a low CTE nickel alloy is desirable.

Various studies on the CTE of Ni-alloys, revealed that $\mathrm{Mn}, \mathrm{Fe}, \mathrm{Co}$ and $\mathrm{Cr}$ increase, while $\mathrm{Mo}, \mathrm{W}, \mathrm{C}, \mathrm{Al}$, and Ti decrease the CTE of Ni [5-10]. Most of the studies on low CTE nickel alloys have focused on developing alloys with CTE's compatible to ferritic and martensitic ferrous alloys used extensively in fossil fueled power plants. These investigations focused on developing alloys for use at temperatures below $700^{\circ} \mathrm{C}$. The present research is aimed at establishing the suitability of low CTE superalloys for use in the SOFC temperature range of 700 to $800^{\circ} \mathrm{C}$. This paper reports on the design, microstructure and oxidation resistance of several low CTE , $\left(12.0\right.$ to $13.0 \times 10^{-6}{ }^{\circ} \mathrm{C}$ from 23 to $\left.800^{\circ} \mathrm{C}\right)$ alloys for potential SOFC applications.

\section{Alloy Design}

Table I lists the composition of the alloys produced for this study. The J series alloys were custom melted (see below), while the others were acquired from their respective commercial suppliers. 
Alloy $\mathrm{J} 1$ is a duplicate of Mitsubishi alloy, LES700 developed in ref. 6. Alloys $\mathrm{J} 3$ and $\mathrm{J} 5$ are derivates of this composition modified for use as an SOFC interconnect. The rationale for the alloy modification scheme is as follows:

- Mn was added to impart the formation of an outer $\mathrm{Cr}-\mathrm{Mn}$ spinel, to minimize $\mathrm{Cr}_{2} \mathrm{O}_{3}$ vaporization in the moist $\mathrm{SOFC}$ environment.

- The reactive element $\mathrm{Y}$, was added to enhance scale adhesion.

- The $\mathrm{Al}$ content was reduced to $0.1 \%$ to minimize $\mathrm{Al}_{2} \mathrm{O}_{3}$ formation $\left(\mathrm{Al}_{2} \mathrm{O}_{3}\right.$ has a high electrical resistivity, and its formation will lower the efficiency of the SOFC).

- Ti was increased to $3 \%$ in alloy 3 for strengthening purposes (via formation of $\mathrm{Ni}_{3} \mathrm{Ti}$ ). The composition of alloy 5 , with 1 $\% \mathrm{Ti}$, was selected to study the influence of $\mathrm{Ti}$ on formability.

- $\quad$ Mo and W were added to lower the CTE mismatch.

The predicted CTE's listed in Table I were calculated using Eq.1, a formulation derived by Yamamoto et. al.[6] for the CTE of Fefree $\mathrm{Ni}$ alloys from room to $700^{\circ} \mathrm{C}$ :

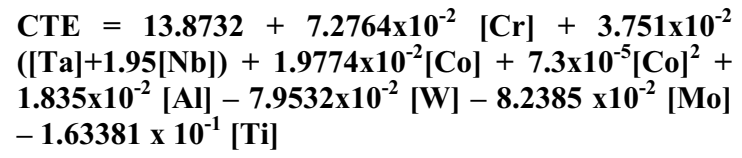

The bracketed terms in this equation represent the concentration (in weight percent, wt $\%$ ) of the specific alloying element.

\section{Experimental Proceedures}

Vacuum induction melting was used to produce $5 \mathrm{~kg}(10 \mathrm{lb})$ ingots. High purity elemental materials were used as starting charges. $\mathrm{Y}$ was added just before casting through an arc melted Ti-Y master alloy. Each melt was cast into a graphite mold $(65 \mathrm{~mm}$ in diameter by $170 \mathrm{~mm}$ long) with a ceramic wash coat. The as-cast ingots were solution annealed at $1150^{\circ} \mathrm{C}$ for 12 hours. The chemistries of the ingots were determined using X-ray florescence (XRF) except for Y content, which was determined by
ICP (see Table I). The measured oxygen content of the ingots ranged from 0.002 to $0.03 \%$, nitrogen from 0.002 to $0.02 \%$, and carbon from 0.01 to $0.09 \%$. After casting, the alloys were reduced to plate by hot working and cold rolling, with the ultimate aim of producing strip material for application. The cast ingots were bagged in a strainless steel foil pouch, preheated for more than 2 hours, upset forged $\sim 15 \%$, and forge flattened $\sim 15 \%$, and finally rolled at $\sim 15 \%$ reduction per pass. Based on ingot chemistries and preliminary experiments with small arc melted buttons, Alloy $\mathrm{J} 1$ was hot worked at $1000^{\circ} \mathrm{C}, \mathrm{J} 5$ was hot worked at $1070^{\circ} \mathrm{C}$ and the other ingots were hot worked at $1150-1170^{\circ} \mathrm{C}$.

Linear variable differential transducer (LVDT) based dilatometer measurements were used to determine the thermal expansion of the alloys in accordance with ASTM standard E-228-85. Samples were $25.4 \times 12.5 \times 6.3 \mathrm{~mm}^{3}$ in size. Length changes were recorded every minute as the specimen was cycled between the temperatures 900 to $23^{\circ} \mathrm{C}$ at an average of $5^{\circ} \mathrm{C} / \mathrm{min}$. The $\mathrm{CTE}$ value was calculated as the secant $\mathrm{CTE}$.

Oxidation coupons were machined from plate material to dimensions of $25.4 \times 12.5 \times 3.175 \mathrm{~mm}^{3}$. A $3.175 \mathrm{~mm}$ diameter hole was drilled into the upper portion of each sample to allow hanging on a quartz rack. Oxidation tests were conducted at 750 and $800^{\circ} \mathrm{C}$. Prior to testing, the surfaces of the coupons were polished through a 600-grit finish. After ultrasonically cleaning in alcohol, the dimensions and weight of each coupon were measured and recorded. Samples were placed on a quartz rack, which was placed inside a pre-heated furnace. Dry air was flowing through the furnace during testing. Approximately every $24 \mathrm{hrs}$ the samples were removed from the furnace, and 1 hour after removal the weight of the coupons was measured and recorded. The samples were then replaced into the furnace for the next cycle.

\section{Results and Discussion}

Alloy $\mathrm{J} 1$ and $\mathrm{J} 5$ proved to be readily workable and were reduced to approximately $2 \mathrm{~mm}$ plate by hot working. These plates were annealed followed by a water quench and cold rolled to $1.27 \mathrm{~mm}$ and $1.6 \mathrm{~mm}$ in 5 and 3 passes for $\mathrm{J} 1$ and $\mathrm{J} 5$, respectively. The strips were reconditioned and cold rolled to a final thickness of

Table I: Alloy compositions and coefficient of thermal expansion (CTE)

\begin{tabular}{|c|c|c|c|c|c|c|c|c|c|c|c|c|}
\hline \multirow{3}{*}{ Alloy } & \multicolumn{8}{|c|}{ Nominal (Actual*) Composition (wt\%) } & \multicolumn{4}{|c|}{ CTE $\left(10^{-6} /{ }^{0} \mathrm{C}\right)$} \\
\hline & \multirow{2}{*}{$\mathrm{Ni}$} & \multirow{2}{*}{$\mathrm{Cr}$} & \multirow{2}{*}{$\mathrm{Ti}$} & \multirow{2}{*}{$\mathrm{Al}$} & \multirow{2}{*}{ Mo } & \multirow{2}{*}{ W } & \multirow{2}{*}{$\mathrm{Mn}$} & \multirow{2}{*}{$\begin{array}{c}\text { Y; } \\
\text { Other }\end{array}$} & \multirow{2}{*}{$\begin{array}{c}\text { Predicted** } \\
23-700^{\circ} \mathrm{C}\end{array}$} & \multicolumn{3}{|c|}{ Measured (range ${ }^{\circ} \mathrm{C}$ ) } \\
\hline & & & & & & & & & & $23-700$ & $23-800$ & $23-900$ \\
\hline $\mathrm{J} 1$ & $\begin{array}{c}\text { Bal } \\
(67.77)\end{array}$ & $\begin{array}{c}12 \\
(12.07)\end{array}$ & $\begin{array}{c}1.1 \\
(1.08)\end{array}$ & $\begin{array}{c}0.9 \\
(0.79)\end{array}$ & $\begin{array}{c}18 \\
(17.85)\end{array}$ & $\begin{array}{l}-- \\
(0)\end{array}$ & $\begin{array}{l}--- \\
(0)\end{array}$ & --- & 13.1 & 12.9 & 13.6 & 14.4 \\
\hline $\mathrm{J} 3$ & $\begin{array}{c}\text { Bal } \\
(61.37) \\
\end{array}$ & $\begin{array}{c}12.5 \\
(12.49) \\
\end{array}$ & $\begin{array}{c}3 \\
(2.85) \\
\end{array}$ & $\begin{array}{c}0.1 \\
(0.14) \\
\end{array}$ & $\begin{array}{c}22.5 \\
(22.22) \\
\end{array}$ & $\begin{array}{l}--- \\
(0)\end{array}$ & $\begin{array}{c}0.5 \\
(0.50) \\
\end{array}$ & $\begin{array}{c}0.1 \mathrm{Y} \\
(0.02) \\
\end{array}$ & 12.4 & 12.3 & 13.4 & 14.3 \\
\hline J5 & $\begin{array}{c}\mathrm{Bal} \\
(63.36)\end{array}$ & $\begin{array}{c}12.5 \\
(12.50)\end{array}$ & $\begin{array}{c}1 \\
(1.02)\end{array}$ & $\begin{array}{c}0.1 \\
(0.038)\end{array}$ & $\begin{array}{c}22.5 \\
(22.17)\end{array}$ & $\begin{array}{l}- \\
(0)\end{array}$ & $\begin{array}{c}0.5 \\
(0.50)\end{array}$ & $\begin{array}{c}0.1 \\
(0.043)\end{array}$ & 12.7 & 12.6 & 13.4 & 14.0 \\
\hline $\mathrm{J} 7$ & $\begin{array}{c}\mathrm{Bal} \\
(41.86) \\
\end{array}$ & $\begin{array}{c}22 \\
(21.84) \\
\end{array}$ & $\begin{array}{c}0 \\
(0.05) \\
\end{array}$ & $\begin{array}{c}0 \\
(0.22) \\
\end{array}$ & $\begin{array}{c}36.1 \\
(35.31) \\
\end{array}$ & $\begin{array}{l}-- \\
(0)\end{array}$ & $\begin{array}{c}0.5 \\
(0.49) \\
\end{array}$ & $\begin{array}{c}0.1 \\
(0.001)\end{array}$ & 12.5 & 11.2 & 11.9 & 12.5 \\
\hline JW9 & $\begin{array}{c}\mathrm{Bal} \\
(55.60)\end{array}$ & $\begin{array}{c}12.5 \\
(14.33)\end{array}$ & $\begin{array}{c}1.1 \\
(1.09)\end{array}$ & $\begin{array}{c}0.9 \\
(0.72)\end{array}$ & $\begin{array}{c}10 \\
(10.30)\end{array}$ & $\begin{array}{c}17 \\
(16.91)\end{array}$ & $\begin{array}{c}0.5 \\
(0.51)\end{array}$ & -- & 12.5 & 12.0 & 12.7 & 13.3 \\
\hline Crofer & $\mathrm{Fe}$ & 22 & 0 & 0 & 0 & 0 & 0.5 & $0.1 \mathrm{La}$ & --- & 11.0 & 11.9 & 12.6 \\
\hline $\begin{array}{c}\text { Haynes } \\
230\end{array}$ & $\mathrm{Bal}$ & 22 & 0 & 0.3 & 2 & 14 & 0.5 & $\begin{array}{c}0.02 \mathrm{La} \\
3 \mathrm{Fe} ; 5 \mathrm{Co}\end{array}$ & --- & 13.3 & 14.3 & 15.4 \\
\hline
\end{tabular}

* determined by XRF, except Y which was determined by ICP; ** predicted using Eq .1 (from Yamamoto et. al., 2002). 


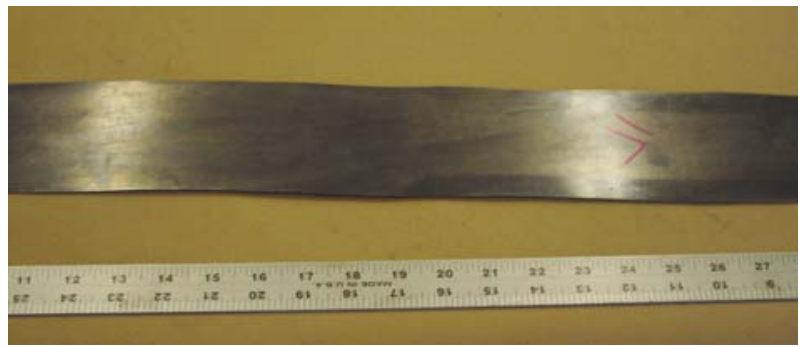

Figure 2. Alloy J1 rolled to $1 \mathrm{~mm}$ thick strip.

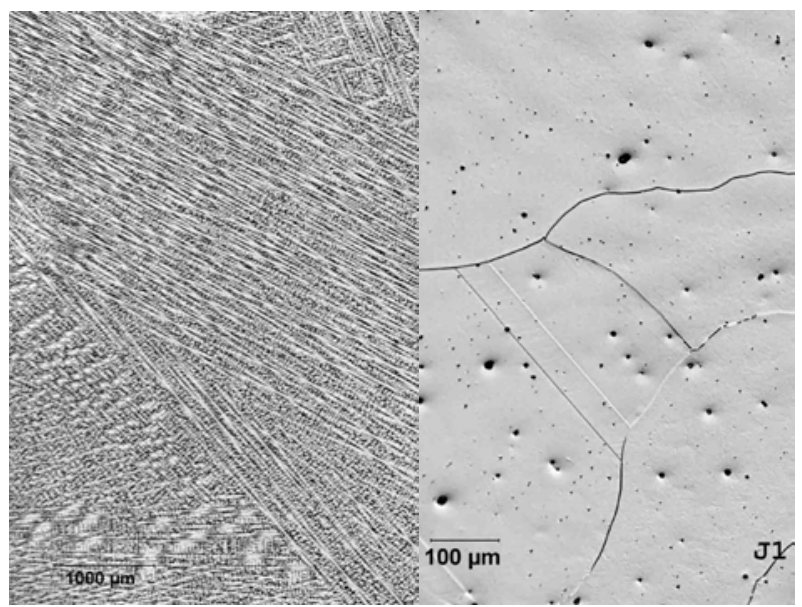

Figure 3. Alloy J1 is shown as cast (left) and after solution annealing at $1150 \mathrm{C} / 12 \mathrm{~h} / \mathrm{FC}$ (right).

0.9 and $1.1 \mathrm{~mm}$ inches for $\mathrm{J} 1$ and $\mathrm{J} 5$, respectively (Figure 2).

Alloy $\mathrm{J} 3$ proved more difficult work, as this alloy needed to be reconditioned several times during hot rolling to $5 \mathrm{~mm}$. Severe edge cracks formed in the plate upon subsequent cold rolling to $4.4 \mathrm{~mm}$. The hardness of the plate increased significantly after one pass (the Rockwell hardness increased from about 23 HRC in the annealed condition to $39 \mathrm{HRC}$ ). Alloy J7 proved to be unworkable; in fact, this alloy was difficult to section with a conventional band saw.

Optical microstructures of the experimental alloys are shown in Figures 3 through 7 . All of the alloys contain secondary phases. Alloy $\mathrm{J} 1$ is shown as-cast, and after solution annealing at $1150 \mathrm{C} / 12 \mathrm{~h} / \mathrm{FC}$ in Figure 3. Figure 4 shows J1 after this alloy was rolled to $1.27 \mathrm{~mm}$. The as-rolled and annealed structure of $\mathrm{J} 1$ is fairly uniform (although some banding of second phase was observed) and the grain size measured as ASTM 6.0. Alloy J3 contains a banded second phase which is shown in the heat tint etched microstructure in Figure 5. Alloy J5 is shown with a heat tint etch in Figure 6. This alloy has a wrought structure with a fairly high degree of twinning and also contains a uniform dispersion of a second phase (i.e., no banding). Alloy J7 did not appear dendritic in the as-cast condition, but rather cellular instead (Figure 7). The hardness of the high volume fraction second phase $\left(>1500 \mathrm{~kg} / \mathrm{mm}^{2}\right)$ clearly contributed to difficulty in working with this alloy. X-ray diffraction identified the this secondary phase as a $\left(\mathrm{Cr}_{2} \mathrm{MoNi}_{2}\right)$ sigma-type phase. The microstructural evolution of alloy JW9 is found in Figure 8. The as-cast structure is indeed dendritic, however there is substantial evidence of second phase particles occurring interdendritically and along grain boundaries. Unlike Alloy J1, solution annealing proved

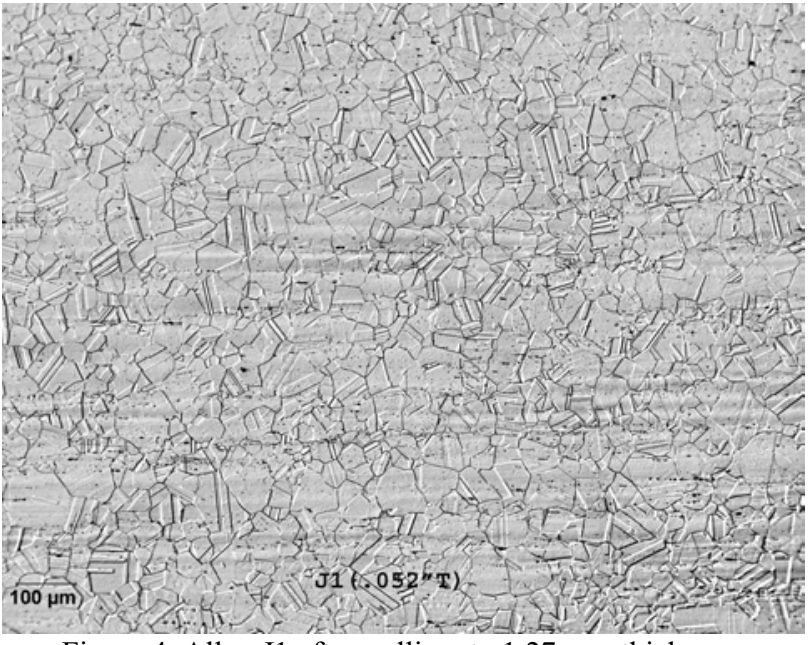

Figure 4. Alloy J1 after rolling to $1.27 \mathrm{~mm}$ thickness.

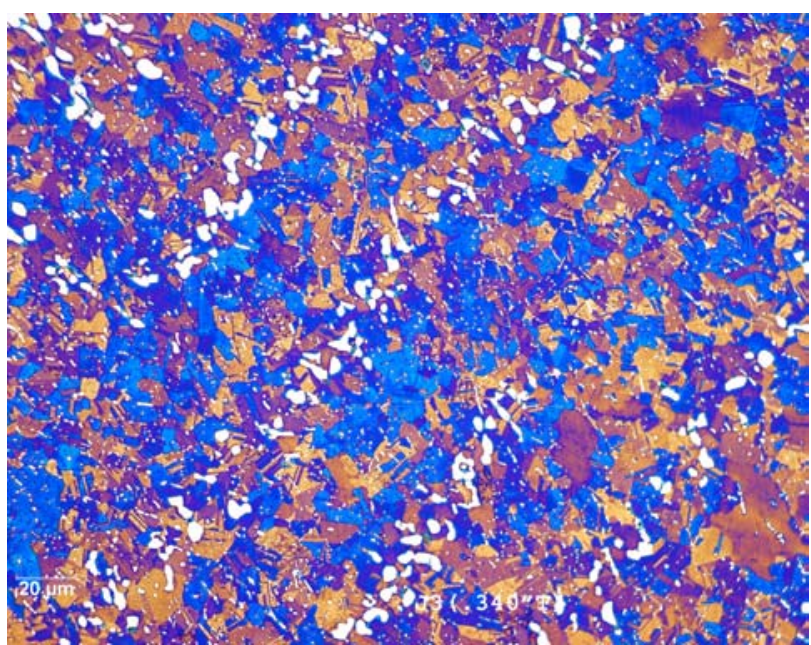

Figure 5. Alloy J3 after hot rolling (at 1170C). Note the banding evident in the heat-tinted microstructure.

unsuccessful in eliminating the second phase. In fact the slow cool down from the solution anneal produced an increase in second phase volume fraction. Isothermal treatments up to $1300^{\circ} \mathrm{C}$ were given to this alloy and none reduce the occurrence of this second phase below that of the as cast material. X-ray diffraction revealed that the second phase was a disordered BCC- phase, based on tungsten.

The predicted and measured CTE for the alloys are also listed in Table I. The results show that the CTE of several of the experimental alloys (J7 and JW9) are in a range suitable for the interconnect application. The results indicate that the CTE formulation (Eq. 1) derived by Yamamoto et al, [6] is reliable for predicting values from room to $700^{\circ} \mathrm{C}$ for alloys $\mathrm{J} 1, \mathrm{~J} 3$ and $\mathrm{J} 5$. Not surprisingly, at $700^{\circ} \mathrm{C}$ Alloy 3 has a lower CTE than Alloy 5 . Alloy 3 contains more $\mathrm{Ti}$, and presumably more gamma prime, than Alloy 5. Morrow et al [9] concluded that increasing gamma prime volume fraction decreases CTE of nickel alloys. However, at $900^{\circ} \mathrm{C}$, the opposite occurs, Alloy 5 has a lower CTE than Alloy 3. It appears that minimization of the gamma prime phase content 


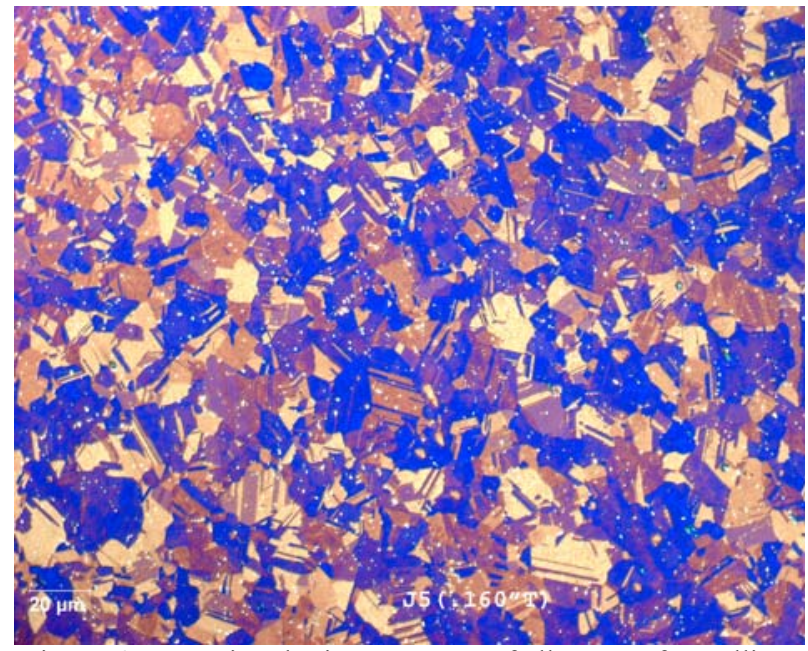

Figure 6. Heat-tinted microstructure of alloys J5 after rolling and annealing at $1070 \mathrm{C} / 15 \mathrm{~min} / \mathrm{WQ}$.

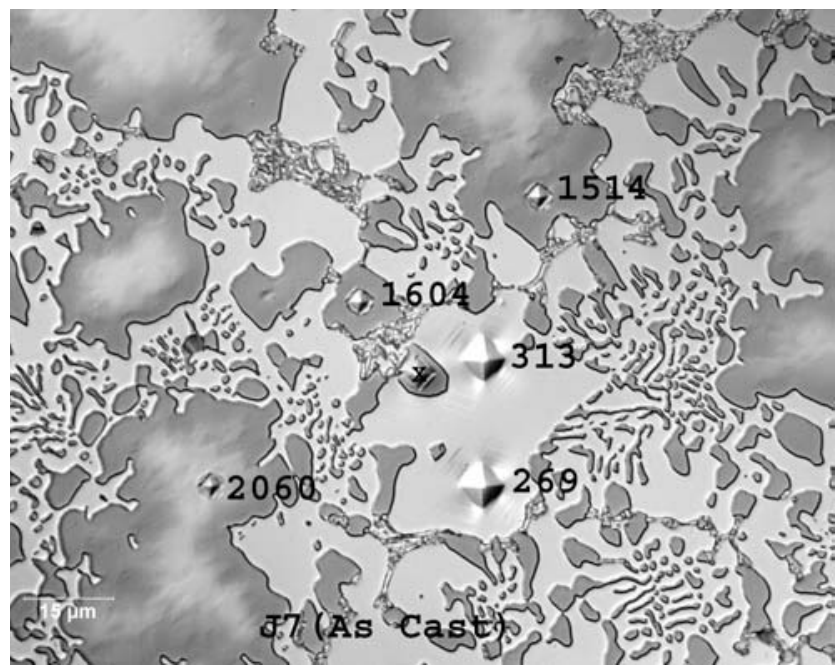

Figure 7. Alloy J7 in the as-cast condition. Note the dark grey phase is substantially harder than the matrix.

may be required to lower $\mathrm{CTE}$ values at elevated temperature. Microstructural studies are underway to correlate the high temperature CTE values with the microstructures of these alloys.

The formulation (Eq. 1), however, was not accurate in predicting the values for alloys J7 and JW9. This is most likely due to the secondary phases present in these alloys. Alloy J7 possessed a cellular structure comprised of sigma and FCC phases. Likewise, alloy JW9 contained a disordered BCC phase. The presence of discrete tungsten rich particles will further suppress the CTE of the alloy, as the CTE of tungsten is $4.6 \times 10^{-6} /{ }^{\circ} \mathrm{C}$ [11]. Presumably, the CTE of $\mathrm{Cr}_{2} \mathrm{MoNi}_{2}$ sigma phase present in alloy $\mathrm{J} 7$ has a lower CTE than the FCC Ni-base phase. It is likely that these alloys behave as a composite material, where the alloy CTE is volumetrically dependent on the CTE of the constituent phases. Therefore, Eq. 1 does not accurately predict the CTE of these alloys.

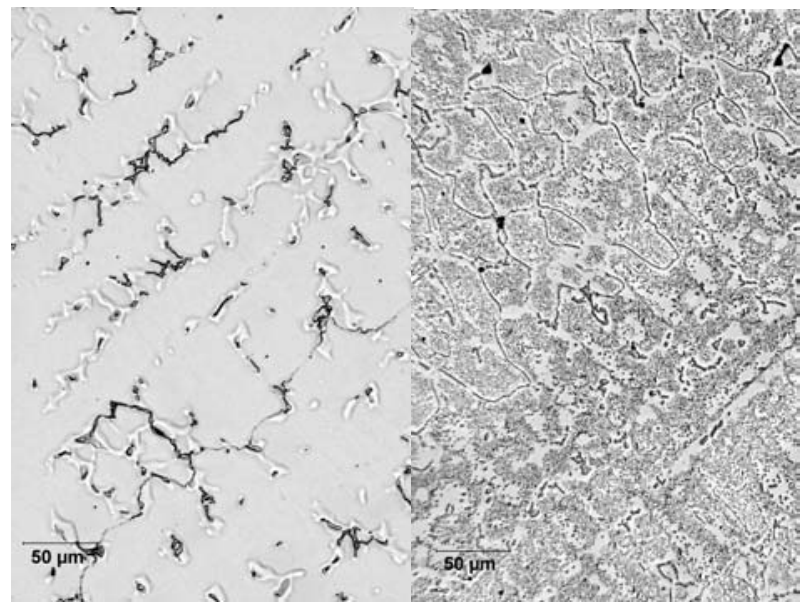

Figure 8. Alloy JW9 is shown as cast (left) and after solution annealing at $1150 \mathrm{C} / 12 \mathrm{~h} / \mathrm{FC}$ (right).

The results of the oxidation testing, clearly show the superior oxidation resistance of Haynes 230 compared to Crofer 22APU (Figure 9). At $750^{\circ} \mathrm{C}$ the ranking of the experimental alloys is as follows: (lowest mass gain) $\mathrm{J} 1<\mathrm{JW} 9=\mathrm{J} 5<\mathrm{J} 3<\mathrm{J} 7$ (highest mass gain). At $800^{\circ} \mathrm{C}$, the ranking is as follows: (lowest mass gain) $\mathrm{J} 1<$ $\mathrm{J} 5<\mathrm{J} 7<\mathrm{J} 3$ (highest mass gain). After 700 hours at $750^{\circ} \mathrm{C}$, the mass gain of alloy J1 was lower than Crofer 22APU. After 300 hours at $800^{\circ} \mathrm{C}$ alloy $\mathrm{J} 1$ had a lower mass gain than Crofer $22 \mathrm{APU}$ and alloy $\mathrm{J} 5$ had a similar mass gain as Crofer 22APU.

Table II lists the oxide species present (determined by $\mathrm{X}$-ray diffraction) on the surface after testing at $800^{\circ} \mathrm{C} . \mathrm{Cr}_{2} \mathrm{O}_{3}$ and a $(\mathrm{Mn}, \mathrm{Cr}, \mathrm{Ni})_{3} \mathrm{O}_{4}$ spinel phase forms on the surface of all the nickelbase alloys; for SOFC applications these are the preferred oxide phases. The exception was alloy $\mathrm{J} 1$, which did not contain Mn, and therefore, no spinel-like phase formed. It is well documented in the literature that the formation of the spinel-like phase leads to increase weight gain during oxidation. Thus, it is not surprising that alloy $\mathrm{J} 1$ displays lower mass gain compared to similar alloys, such as J5, that contain Mn and form the spinel phase. The initial rapid increase in the mass gain of the experimental alloys may be explained by the formation of the other less protective oxides (such as $\mathrm{NiO}, \mathrm{TiO}_{2}$ and $\mathrm{NiMoO}_{4}$ ). These oxides form during the initial stages of exposure, and with increasing exposure times the $\mathrm{Cr}_{2} \mathrm{O}_{3}$ scale grows to cover and protect the entire surface. The reason alloy $\mathrm{J} 7$ (the $22 \mathrm{wt} \% \mathrm{Cr}$ ) displays poor oxidation resistance compared to the lower $\mathrm{Cr}$ alloys, can be explained by the formation of non-protective $\mathrm{Ni}_{3} \mathrm{MoO}$ and $\mathrm{NiMoO}_{4}$ oxides. This is a consequence of the distributed sigma phase found in this alloy.

As mentioned above, once the more stable $\mathrm{Cr}_{2} \mathrm{O}_{3}$ oxide covers the surface of the experimental alloys (J1, J5 and JW9), the rate of oxidation decreases. The mass gain versus time behavior of the nickel alloys appears to behave in a parabolic manner, where as for Crofer 22APU the mass gain steadily increases with time. Thus, initially the oxidation rate of the experimental alloys appears accelerated compared to Crofer 22APU. As time progresses, however, the oxidation rates of the experimental alloys decrease relative to Crofer 22APU. Figure 10 extrapolates the mass gain of the alloys over 40,000 hours. The extrapolation is based on the 3300 hour oxidation data shown in Figure 9a. Figure 10 indicates that even the Ni-base alloys with much lower $\mathrm{Cr}$ 


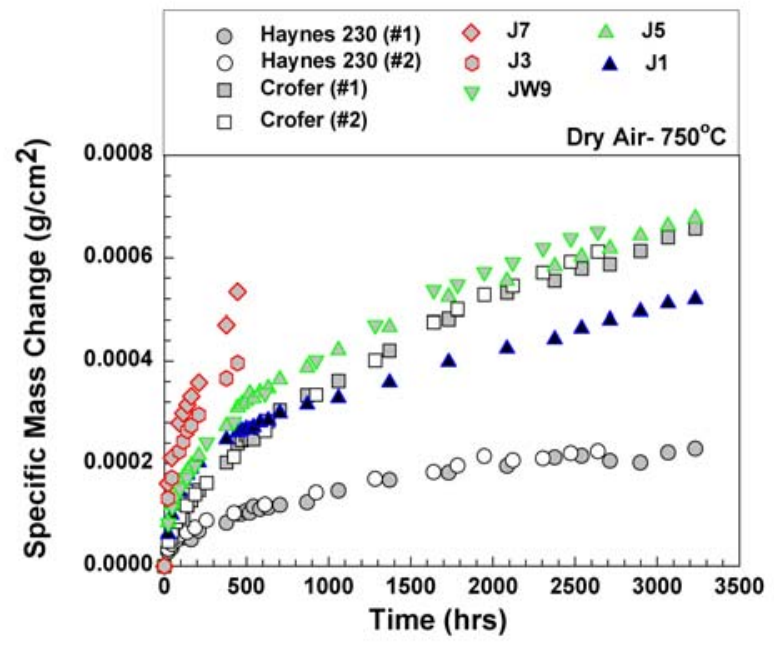

(a)

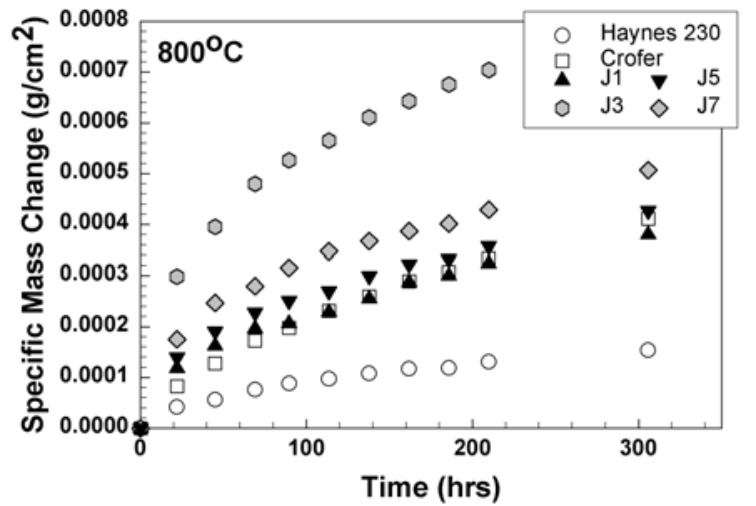

(b)

Figure 9. Oxidation behavior in dry air at: (a) $750^{\circ} \mathrm{C}$; and (b) $800^{\circ} \mathrm{C}$.

contents will be more oxidation resistant than Crofer 22APU over this time range. The curve fits predict that the mass change for alloy J5 will be less than that of Crofer 22APU after an exposure time of about $5000 \mathrm{hrs}$. After $40,000 \mathrm{hrs}$, alloy J5 will be 1.25 times more oxidation resistant and alloy $\mathrm{J} 1$ will be 2 times more oxidation resistant than Crofer 22APU (based on the predicted specific mass gains).

\section{Conclusion}

The results show that nickel base alloys with CTE in a useful range for SOFC interconnect application can be produced. Oxidation tests in dry air showed that these alloys can have superior oxidation resistance to an Fe-base alloy developed specifically for an SOFC interconnect. However, a by-product of the chemical reaction within the cell is $\mathrm{H}_{2} \mathrm{O}$. The presence of $\mathrm{H}_{2} \mathrm{O}$ has been found to be detrimental to the stability of the chrome oxides that form on the surface [12,13]. Thus, evaluating the environmental resistance of the alloys in moist air is a requirement for this application. Further, the interconnect experiences a dual environment, i.e., oxidizing on one side reducing on the other. Exposure to this dual environment has also been found to significantly degrade the environmental resistance of a variety of different alloys [14,15]. Work is continuing at the Albany Research Center to evaluate the performance of these experimental alloys in a simulated SOFC environment; as well as research to tailor the composition and microstructure of these

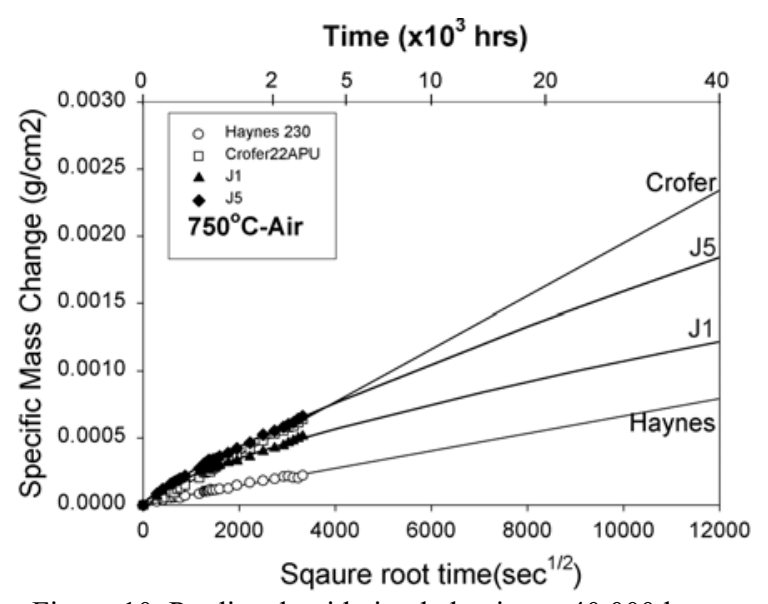

Figure 10. Predicted oxidation behavior to 40,000 hours.

Table II: Oxides formed on surface of alloys Testing in dry air at $800^{\circ} \mathrm{C}$ for $305 \mathrm{hrs}$ (Phases determined by X-Ray diffraction)

\begin{tabular}{|c|c|}
\hline Alloy & Oxides Present \\
\hline Haynes 230 & $\begin{array}{l}\text { Primary: } \mathrm{Cr}_{2} \mathrm{O}_{3} \\
\text { Secondary: }(\mathrm{Mn}, \mathrm{Cr}, \mathrm{Ni})_{3} \mathrm{O}_{4} \text { Spinel }\end{array}$ \\
\hline Crofer 22APU & $\begin{array}{l}\text { Primary: }(\mathrm{Mn}, \mathrm{Cr}, \mathrm{Fe})_{3} \mathrm{O}_{4} \text { Spinel } \\
\text { Secondary: } \mathrm{Cr}_{2} \mathrm{O}_{3}\end{array}$ \\
\hline J1 & $\begin{array}{l}\text { Primary: } \mathrm{Cr}_{2} \mathrm{O}_{3} \\
\text { Secondary: } \mathrm{NiO} \\
\text { Minor/Trace: } \mathrm{NiMoO}_{4}, \mathrm{Ni}_{3} \mathrm{TiO}_{5}\end{array}$ \\
\hline $\mathrm{J} 3$ & $\begin{array}{l}\text { Primary: } \mathrm{Cr}_{2} \mathrm{O}_{3} \\
\text { Secondary: }(\mathrm{Mn}, \mathrm{Cr}, \mathrm{Ni})_{3} \mathrm{O}_{4} \text { Spinel } \\
\text { Minor/Trace: } \mathrm{TiO}_{2}, \mathrm{NiMoO}_{4}\end{array}$ \\
\hline J5 & $\begin{array}{l}\text { Primary: } \mathrm{Cr}_{2} \mathrm{O}_{3} \\
\text { Secondary: }(\mathrm{Mn}, \mathrm{Cr}, \mathrm{Ni})_{3} \mathrm{O}_{4} \text { Spinel } \\
\text { Minor/Trace: } \mathrm{TiO}_{2}\end{array}$ \\
\hline $\mathrm{J} 7$ & $\begin{array}{l}\text { Primary: } \mathrm{Cr}_{2} \mathrm{O}_{3} \\
\text { Secondary: }(\mathrm{Mn}, \mathrm{Cr}, \mathrm{Ni})_{3} \mathrm{O}_{4} \text { Spinel } \\
\text { Minor/Trace: } \mathrm{Ni}_{3} \mathrm{MoO}, \mathrm{NiMoO}_{4}\end{array}$ \\
\hline
\end{tabular}

alloys to produce materials with desirable performance characteristics for the SOFC applications.

\section{Acknowledgements}

The assistance of Mr. Ed Argetsinger with the fabrication of the alloys, Mr. Paul Danielson with metallography and Mr. Dale Govier with X-ray diffraction, is greatly acknowledged.

\section{References}

1. Solid State Energy Conversion Alliance (SECA) Program Plan, U.S. DOE., National Energy Technology Laboratory Morgantown WV, January 2002 (available on line at www.seca.doe.gov).

2. Fuel Cell Handbook, $6^{\text {th }}$ Edition National Energy Technology Laboratory, Morgantown WV, November 2002 (available through www.netl.doe.gov).

3. P. Kofstad, K.P. Lillerud, J. Electrochem. Soc. 127, 1980, p.2410. 
4. G. Yang, J. Stevenson, P. Singh, "White Paper: Haynes 230 vs. Crofer 22APU” PNNL, Richland, Wa,. June 2003.

5. D.R. Muzyka, C.R. Whitney, D.K. Schlosser, JOM, vol 11, July, 1975, p.11.

6. R. Yamamoto, et. al., in Materials for Advanced Power Engineering -2002 , Proc. $7^{\text {th }}$ Leige Conf. Sept 30-Oct 3, 2002, Energy and Technology Vol 21., Forschungszentium Julich Gmbh Inst. Fur Werkstoffe und Verfahren der Energietechnik.

7. S.K. Hwang, F.C. Hull, J.M. Wells, in Superalloys-1984, TMS, Warrendale, PA, p. 785.

8. J.M. Wells, S.K. Hwang and F.C. Hull, in Refractory Alloying Elements in Superalloys, ASM, Materials Partk, OH, 1984, p. 175.

9. H. Morrow, D.L. Sponseller, M. Semchyhsen, Metall. Trans. A, 6A, 1975, p. 477.

10. P.K. Sung, D.R. Poirier, Mat. Sci. Engr. A245, 1998, p. 135.

11. Smithells Metal Reference Book, E.A Brandes and G.B. Brook eds., Butterworth-Hienmann Ltd., Oxford (U.K.), 1992, p.14-5.

12. G.H. Meier, in Proc. Solid State Energy Conversion Alliance - Core Technologies Review Meeting, Sept. 30, 2003, DOE, National Energy Technology Laboratory Morgantown WV, 2003 (available on line at www.seca.doe.gov)

13. P.Kofstad, High Temperature Corrosion, Elsevier Applied Science, London, 1988, p.382-385.

14. M. Ziomek-Moroz, S.Cramer, G. Holcomb, B. Covino, S. Matthes, S. Bullard, J. Dunning, D. Alman, and P. Singh, in 2003 Fuel Cell Seminar, p.522-525.

15. Z.G. Yang, M. Walker, G. Xia, P. Singh and J. Stevenson, in Proc. Solid State Energy Conversion Alliance - Core Technologies Review Meeting, Sept. 30, 2003, DOE., National Energy Technology Laboratory Morgantown WV, 2003 (available on line at www.seca.doe.gov). 